\title{
Ghrelin Increases Beta-Catenin Level through Protein Kinase A Activation and Regulates OPG Expression in Rat Primary Osteoblasts
}

\author{
Emanuela Mrak, ${ }^{1}$ Lavinia Casati, ${ }^{1}$ Francesca Pagani, ${ }^{1}$ Alessandro Rubinacci, ${ }^{2}$ \\ Guido Zarattini, ${ }^{3}$ and Valeria Sibilia ${ }^{1}$ \\ ${ }^{1}$ Department of Medical Biotechnology and Translational Medicine, Medical Pharmacology Unit, Università degli Studi di Milano, \\ Via Vanvitelli 32, 20129 Milano, Italy \\ ${ }^{2}$ Bone Metabolism Unit, Scientific Institute San Raffaele, Via Olgettina 60, 20132 Milano, Italy \\ ${ }^{3}$ Department of Medical and Surgical Specialties, Radiological Sciences and Public Health, University of Brescia, \\ Viale Europa 11, 25123 Brescia, Italy
}

Correspondence should be addressed to Valeria Sibilia; valeria.sibilia@unimi.it

Received 10 December 2014; Revised 1 March 2015; Accepted 2 March 2015

Academic Editor: Oreste Gualillo

Copyright (C) 2015 Emanuela Mrak et al. This is an open access article distributed under the Creative Commons Attribution License, which permits unrestricted use, distribution, and reproduction in any medium, provided the original work is properly cited.

Ghrelin, by binding growth hormone secretagogue receptor (GHS-R), promotes osteoblast proliferation but the signaling mechanism of GHS-R on these cells remains unclear. Since canonical Wnt/ $\beta$-catenin pathway is critically associated with bone homeostasis, we investigated its involvement in mediating ghrelin effects in osteoblasts and in osteoblast-osteoclast cross talk. Ghrelin $\left(10^{-10} \mathrm{M}\right)$ significantly increased $\beta$-catenin levels in rat osteoblasts (rOB). This stimulatory action on $\beta$-catenin involves a specific interaction with GHS-Rla, as it is prevented by the selective GHS-Rla antagonist, D-Lys ${ }^{3}-\mathrm{GHRP}-6$ (10 $\left.{ }^{-7} \mathrm{M}\right)$. The effect of ghrelin on $\beta$-catenin involves the phosphorylation and inactivation of GSK- $3 \beta$ via protein kinase A (PKA). Inhibition of PKA activity reduces the facilitatory action of ghrelin on $\beta$-catenin stabilization. Ghrelin treatment of rOB significantly increases the expression of osteoprotegerin (OPG), which plays an important role in the regulation of osteoclastogenesis, and this effect is blocked by D-Lys ${ }^{3}$-GHRP-6. Furthermore, ghrelin reduced RANKL/OPG ratio thus contrasting osteoclastogenesis. Accordingly, conditioned media from $\mathrm{rOB}$ treated with ghrelin decreased the number of multinucleated TRAcP+ cells as compared with the conditioned media from untreated-control rOB. Our data suggest new roles for ghrelin in modulating bone homeostasis via a specific interaction with GHSR-1a in osteoblasts with subsequent enhancement of both $\beta$-catenin levels and OPG expression.

\section{Introduction}

Accumulating evidence, including in vitro and in vivo studies in animal models as well as observational studies in humans, indicate a role for ghrelin in the control of bone cell activities [1-4].

Ghrelin, an endogenous ligand of the GH secretagogue receptor (GHS-R), and its receptor GHS-Rla are expressed in several osteoblasts and osteoblastic cell lines. Ghrelin directly promotes both osteoblast proliferation and differentiation [5$8]$ and inhibits apoptosis of MC3T3-E1 cells [6, 9]. Moreover, recent data suggest that GHS-Rla expression is subjected to an epigenetic regulation through DNA methylation and histone modification. Changes in the epigenetic status of the cell might therefore play an important role in determining sensitivity to ghrelin [10].

In addition to a well characterized anabolic action, the data regarding the effects of ghrelin on osteoclastogenesis are contradictory. Costa et al. [8] have shown that ghrelin increases the bone resorption activity of rat osteoclasts but did not modify osteoclast differentiation in a murine bone marrow assay or bone resorption in ex vivo calvarial culture. More recently, van der Velde et al. [11] found that ghrelin has dual actions in osteoclasts since it inhibits osteoclast progenitors locally and exerts an age-dependent stimulatory action on osteoclastogenesis via a systemic pathway. 
In vivo studies showed that intraperitoneal [5] as well as central administration [12] of ghrelin increases bone mineral density and mass through a mechanism independent of $\mathrm{GH}$ IGF1 axis and appetite regulation, respectively. Consistently, synthetic GH secretagogues increase bone mineral density [13] and prevent gonadectomy-induced bone loss in the rat $[14,15]$. Data from clinical studies are limited but indicate a positive association between circulating ghrelin levels and bone mineral density in women $[16,17]$ and elderly men [18].

Despite convincing evidence that ghrelin has positive effects on bone metabolism, the signaling mechanism and the specific involvement of GHS-Rla in osteoblast are still controversial [19] and remain unclear. Since the canonical $\mathrm{Wnt} / \beta$-catenin pathway is critically associated with the entire osteoblast life cycle, that is, commitment, proliferation, apoptosis, and function, we hypothesized that ghrelin exerts its anabolic action in bone through canonical Wnt signaling and $\beta$-catenin stabilization. This hypothesis is supported by the observation that in rat cortical neuron cells ghrelin exerts specific, receptor mediated antiapoptotic effects by activating ERK1/2 pathway and by stabilizing $\beta$-catenin via PI3K/Aktmediated inactivation of glycogen synthase kinase (GSK-3 $\beta$ ) [20].

Wnt canonical signaling pathway relies on the cytosolic stabilization of $\beta$-catenin, which is a 130 amino acid protein that, in the absence of Wnt proteins, is phosphorylated by GSK- $3 \beta$ and degraded through the proteosomal machinery. When not degraded, stable $\beta$-catenin is accumulated in the cytoplasm and upon reaching a certain concentration level is translocated into the nucleus to stimulate gene transcription [21].

To test our hypothesis, we first examined the effects of increasing concentrations of ghrelin on $\beta$-catenin intracellular levels in primary rat osteoblasts. Then, we characterized the receptor involved in the stimulatory action of ghrelin on $\beta$-catenin and examined the effects of ghrelin on the expression of osteoprotegerin (OPG) a target gene of $\beta$-catenin that plays an important role in osteoblasts and osteoclasts cross talk. Furthermore, we evaluated whether or not ghrelin, by modulating the OPG/RANKL/RANK system, could influence osteoclastogenesis in cultured rat osteoclast precursors cells.

\section{Materials and Methods}

2.1. Drugs. Ghrelin was synthesized by conventional solid phase synthesis and purified to at least $98 \%$ purity by HPLC by Neosystem (Strasburg, France). D-Lys ${ }^{3}$-GHRP-6 was purchased from Bachem AG (Dubendorf, Switzerland). H89 was from Sigma, Milan, Italy. Rat macrophage colony-stimulatory factor (M-CSF) and rat RANKL were from Peprotech, Rocky Hill, NJ.

2.2. Rat Osteoblast-Like Cells. Parietal and frontal calvariae (4 per animal) were explanted aseptically from 3-day-old Sprague Dawley rats. After removing the periosteum, the calvariae were cut in small pieces and placed in Joklik's modified MEM (Sigma, Milan, Italy) serum-free medium containing
$0.5 \mathrm{mg} / \mathrm{mL}$ type IV collagenase (Sigma, Milan, Italy) for 20 minutes at $37^{\circ} \mathrm{C}$ with rotation. Digestion was stopped by the addition of Dulbecco's medium (DMEM, Euroclone, Milan, Italy) containing $10 \%$ foetal bovine serum (FBS, Euroclone). Calvariae obtained from three animals were plated in $75 \mathrm{~cm}^{2}$ flask and allowed to grow to confluence in DMEM containing $10 \%$ FBS, $100 \mathrm{U} / \mathrm{mL}$ penicillin, $100 \mathrm{mg} / \mathrm{mL}$ streptomycin, and $0.25 \mathrm{mg} / \mathrm{mL}$ amphotericin $\mathrm{B}$; the culture medium was changed every 2-3 days. Cells reached confluence after approximately one week. The cell population was tested for alkaline phosphatase production after PTH $10^{-8} \mathrm{M}$ treatment for $48 \mathrm{~h}$ to ensure that the cells were endowed with osteoblast characteristics. Cells were all used at first passage to reduce the possibility of phenotype changes.

2.3. Cell Viability Assay. Cells were plated at the density of $3 \times$ $10^{3}$ cells/well in a 96-well culture plate. After treatment, cells were washed with phosphate buffered saline (PBS, Euroclone, Italy) and incubated at $37^{\circ} \mathrm{C}$ with $0.5 \mathrm{mg} / \mathrm{mL} 3$-(4,5-dimethyl2-thiazolyl)-2,5-diphenyltetrazoliumbromide (MTT, SigmaAldrich Chemical, Italy) for $3 \mathrm{~h}$. The conversion of the tetrazolium salt MTT to a colored formazan was used to assess cell viability. After the supernatant was removed, dimethyl sulfoxide was added to each well and the absorbance was recorded by a microplate spectrophotometer (WALLAC) at $550 \mathrm{~nm}$.

Cell phenotypic observations were made using Olympus TH4-200 inverted phase-contrast microscope, fitted with a digital camera Olympus C-4040 zoom to record any change during treatment.

2.4. Western Blot Analysis. Confluent cells plated in 6-well multiwell plates were treated with ghrelin $10^{-11}-10^{-7} \mathrm{M}$ for $15,30,60,90$, and $120 \mathrm{~min}$; the GHSR1a receptor antagonist, D-Lys ${ }^{3}$-GHRP-6 $\left(10^{-7} \mathrm{M}\right)$, was added 30 min before ghrelin $10^{-10} \mathrm{M}$; incubation with $2 \times 10^{-6} \mathrm{M} \mathrm{H} 89$, an inhibitor of PKA activity, was performed $30 \mathrm{~min}$ before ghrelin $10^{-10} \mathrm{M}$.

After removing the medium, adherent cells were gently scraped into $75 \mu \mathrm{L}$ RIPA buffer ( $1 \%$ triton X100, 0.5\% Sodium deoxycholate, $0.1 \%$ Sodium Dodecyl Sulphate) per well. Two wells were collected for each treatment. Total protein concentration was determined by BCA assay (Pierce, Rockford, IL). Thirty micrograms of total protein extract was mixed with the appropriate volume of Laemmli's sample loading buffer, heated at $100^{\circ} \mathrm{C}$ for $5 \mathrm{~min}$ and loaded onto $10 \%$ SDS polyacrylamide gels. Western blots were performed using a specific antibody against rat $\beta$-catenin diluted 1:5000 in 5\% milk in Tris- $\mathrm{HCl}$ with $0.1 \%$ Tween-20 (TBST); rat P-GSK3 $\beta$ (1:2000 $5 \%$ milk in TBST); rat total GSK3 $\beta$ ( $1: 20005 \%$ milk in TBST) (Cell Signaling Technology, Boston, MA) or against rat $\beta$ actin (1:2000 5\% milk in TBST) (Santa Cruz Biotechnology, Inc., Heidelberg, Germany). Nuclear fractions were isolated from untreated cells or cells treated with ghrelin $\left(10^{-10} \mathrm{M}\right)$ alone or in association with D-Lys ${ }^{3}$-GHRP-6 $\left(10^{-7} \mathrm{M}\right)$ by the Qproteome Cell Compartment Assay (Qiagen SpA, Milan, Italy) that allows selectively isolating proteins in different cell compartments by sequential addition of different extraction 
buffers to a cell pellet. Scion Image software (Scion Corp., Frederick, MD) was used to quantify the Western blots. $\beta$ Actin or Tot-GSK3 $\beta$ was used as endogenous controls to avoid incorrect estimations of the signal from the protein of interest. The intensity of the treated samples was normalized to that of the untreated samples (set as 1) and presented as a ratio of untreated controls.

2.5. Real-Time PCR. Osteoprotegerin (OPG), $\beta$-catenin, receptor activator of NFkB ligand (RANKL), and Dickkopf 1 (DKK1) mRNA relative expression were evaluated by realtime PCR after exposing $\mathrm{rOB}$ at confluence to ghrelin $10^{-11} \mathrm{M}-10^{-7} \mathrm{M}$ for 1,4 , and $24 \mathrm{~h}$ in serum-free medium. In order to assess if the effect of ghrelin on OPG gene expression was receptor mediated, cells were pretreated with D-Lys ${ }^{3}$-GHRP-6 $10^{-7}$ M 30 min before adding ghrelin. Total RNA was extracted using TRIzol according to the manufacturer's instructions (Invitrogen Life Technology, Inc., Paisley, UK). RNA pellet concentrations were assessed spectrophotometrically using Epoch Spectrophotometer System (Biotek) (OD260/280). Two micrograms of total RNA were retrotranscribed in a total volume of $25 \mu \mathrm{L}$ using an oligodT primer (0.5 mM), $200 \mathrm{U}$ of M-MLV reverse transcriptase, deoxynucleotides $(0.5 \mathrm{mM}), \mathrm{M}-\mathrm{MLV}$ reaction Buffer $1 \mathrm{x}$, and rRNasin ribonuclease inhibitor $1 \mathrm{U} / \mathrm{mL}$ (Promega Corporation, Madison, WI). Relative quantification of OPG $\beta$-catenin, RANKL, and DKK1 was performed on an ABI PRISM 7900 sequence detector (Applied Biosystems, Foster City, CA) using $20 \mathrm{ng}$ cDNA of the RT-PCR solution in a final volume of $25 \mu \mathrm{L}$. The primer-probe sets were purchased as assay-on-demand for gene expression from Applied Biosystems. Real-time PCR was performed with FAM-labelled specific probes for OPG, $\beta$-catenin, RANKL, and DKK1 detection and VIClabelled probes for the detection of the housekeeping gene glyceraldehyde-3-phosphate dehydrogenase (GAPDH), used as an endogenous control. Real-time PCR was run according to the following protocol: an initial step of $2 \mathrm{~min}$ at $50^{\circ} \mathrm{C}$ and $10 \mathrm{~min}$ at $95^{\circ} \mathrm{C}$ followed by 40 cycles of $15 \mathrm{sec}$ at $95^{\circ} \mathrm{C}$ and $1 \mathrm{~min}$ at $60^{\circ} \mathrm{C}$. mRNA levels were quantified using the comparative threshold-cycle $(\mathrm{Ct})$ method.

2.6. Osteoclastogenesis Assay. Osteoclast precursors cells were obtained from 3-day-old rat pups long bones. Bone marrow was flushed out with DMEM and the cell suspension was pushed through needles of decreasing size (19 G$25 \mathrm{G}$ ) until homogenously resuspended. Cells were then centrifuged and plated in petri dishes in DMEM supplemented with $10 \% \mathrm{FBS}, 100 \mathrm{U} / \mathrm{mL}$ penicillin, $100 \mathrm{mg} / \mathrm{mL}$ streptomycin, and $0.25 \mathrm{mg} / \mathrm{mL}$ amphotericin $\mathrm{B}$ in the presence of $\mathrm{M}$ CSF $(100 \mathrm{ng} / \mathrm{mL})$ for $48 \mathrm{~h}$. Nonadherent erythrocytes were removed while adherent bone marrow cells were washed with PBS resuspended in culture medium and plated on 96-well plates $\left(10^{4}\right.$ cells/well) with M-CSF $(25 \mathrm{ng} / \mathrm{mL})$ and RANK-L $(50 \mathrm{ng} / \mathrm{mL})$ for osteoclast generation in presence of $50 \%$ of conditioning medium derived from $\mathrm{rOB}$ treated with ghrelin $10^{-10} \mathrm{M}$ for $24 \mathrm{~h}, 48 \mathrm{~h}$, or untreated. Half of the media was changed every day and cytokines were added freshly. After 5 days of culture cells were fixed with $4 \%$ paraformaldehyde in PBS for $10 \mathrm{~min}$ and osteoclast formation was assessed by tartrate resistant acid phosphatase (TRAcP) staining. Briefly, fixed cells were incubated with naphthol-ASBI-phosphate, pararosanilin, and tartrate in acetate buffer $(30 \mu \mathrm{M})$ at $37^{\circ} \mathrm{C}$ for $45 \mathrm{~min}$. TRAcP positive cells with three or more nuclei were considered to be osteoclasts.

2.7. Statistical Analysis. Statistical analysis was performed with a statistic package (GraphPad Prism 5, GraphPad Software San Diego, CA, USA). All data are represented as the mean \pm SEM. Differences between groups were assessed by one-way analysis of variance (ANOVA) for nonparametric data (Kruskal-Wallis test) followed by a multiple comparison test (Dunn's test) and by Mann-Whitney $U$ test when comparing two groups only. A probability of $P<0.05$ was considered to be significant.

\section{Results}

To examine the effects of ghrelin on $\beta$-catenin levels, primary rat osteoblast-like cells were treated for $60 \mathrm{~min}$ with increasing ghrelin concentrations. Using Western blot analysis, we have shown that ghrelin significantly increased $\beta$-catenin levels starting from $10^{-10} \mathrm{M}$ to $10^{-8} \mathrm{M}$ (Figure 1). Although the observed increment was small, it was dose and time dependent, thus indicating its specificity.

The stimulatory action of ghrelin on $\beta$-catenin involves GSK-3 $\beta$ phosphorylation and inactivation as shown by the significant increase of phosphorylated GSK-3 $\beta$ induced by ghrelin $\left(10^{-10} \mathrm{M}\right)$ starting from $30 \mathrm{~min}$ of incubation (Figure 2).

In order to study whether the observed $\beta$-catenin stabilization induced by ghrelin involves a specific interaction with its GHS-Rla, primary rat osteoblast-like cells were treated for $30 \mathrm{~min}$ with the selective GHS-Rla antagonist, D-Lys ${ }^{3}$-GHRP-6 $\left(10^{-7} \mathrm{M}\right)$, and then challenged with ghrelin $\left(10^{-10} \mathrm{M}\right) . \beta$-catenin levels were measured in both the cytosolic and nuclear compartments after fractioning of the whole cell lysate. Pretreatment with D-Lys ${ }^{3}$-GHRP- 6 abolished both ghrelin-induced cytoplasm $\beta$-catenin stabilization and $\beta$ catenin nuclear migration (Figure 3 ), indicating that the effects of ghrelin on $\beta$-catenin are due to a specific interaction of the peptide with GHS-Rla.

We then explored the intracellular signaling pathways involved in the stimulatory action of ghrelin on $\beta$-catenin levels following its binding to GHS-Rla. Our data demonstrate that $10^{-10} \mathrm{M}$ ghrelin activates cAMP/PKA pathway since a PKA inhibitor, H89, reduced both ghrelin-induced $\beta$ catenin stabilization (Figure $4(\mathrm{a})$ ) and GSK-3 $\beta$ phosphorylation (Figure 4(b)).

To further confirm that ghrelin exerts its anabolic action by interacting with GHS-Rla via PKA activation, osteoblast viability was assessed after pretreatment with D-Lys ${ }^{3}$-GHRP6 (Figure 5(a)) and after inhibition of PKA activity by H89 (Figure 5(b)). As shown, ghrelin increases significantly cell viability whereas both pretreatments nullified it.

Considering that OPG is a target gene of $\beta$-catenin, we examined the effects of increasing ghrelin concentrations 


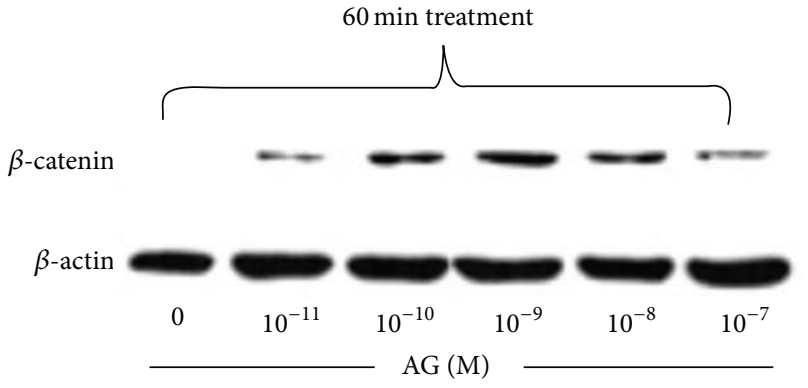

(a)

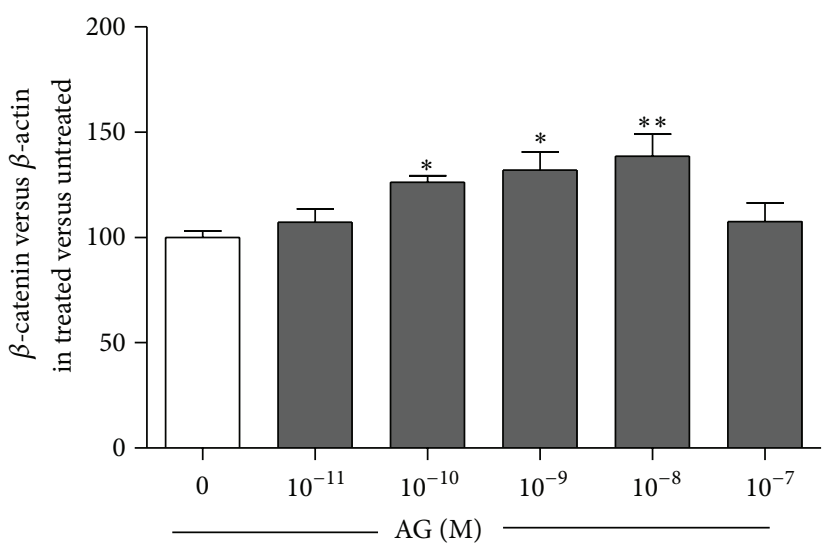

(b)

FIGURE 1: Representative Western blot (a) and quantification (b) of the effect of increasing concentrations of ghrelin $\left(\mathrm{AG}, 10^{-11}-10^{-7} \mathrm{M}, 1 \mathrm{~h}\right.$ treatment) on $\beta$-catenin protein level in whole cell lysates of rat osteoblast-like cells. $\beta$-catenin levels are normalized on $\beta$-actin protein levels and results are expressed as the ratio of $\beta$-catenin amount measured in treated cells to the amount obtained in untreated cells. Data are the mean \pm SEM of five experiments ${ }^{*} P<0.05,{ }^{* *} P<0.01$ versus untreated cells.



(a)

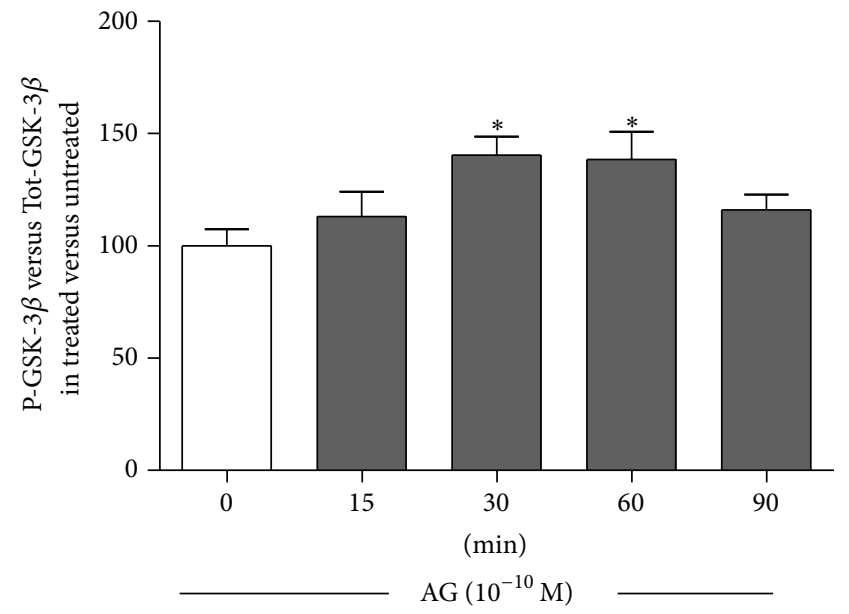

(b)

FIGURE 2: Representative Western blot (a) and quantification (b) of timecourse experiments performed on rat osteoblast-like cells treated with ghrelin $\left(\mathrm{AG}, 10^{-10} \mathrm{M}\right)$ for $15,30,60$, and $90 \mathrm{~min}$. Phosphorylated-GSK-3 $\beta$ (P-GSK-3 $\beta$ ) levels were measured in whole cell lysates and normalized to total GSK- $3 \beta$ levels (Tot-GSK3 $\beta$ ). Results are shown as ratio of P-GSK3 $\beta$ measured in treated versus untreated cells. Data are the mean \pm SEM of 5 experiments ${ }^{*} P<0.05$, versus untreated cells.

on the expression of OPG, $\beta$-catenin, and DKK1 measured by real-time PCR. Primary rat osteoblast-like cells treated for $24 \mathrm{~h}$ with ghrelin $\left(10^{-10} \mathrm{M}\right)$ showed a significant increase in the expression of OPG. This ghrelin action involves an interaction with GHS-Rla since it was removed by pretreatment with D-Lys ${ }^{3}$-GHRP-6 (Figures 6(a) and 6(b)). We next examined the effects of increasing ghrelin concentration on RANKL expression. Ghrelin had no significant effect on RANKL mRNA but significantly reduced RANKL/OPG ratio at $10^{-10} \mathrm{M}$ (Figure $6(\mathrm{c})$ ). No significant effect on $\beta$-catenin and DKK1 expressions at 1,4 , and 24 h of exposure to different doses of ghrelin (from $10^{-11} \mathrm{M}$ to $10^{-7} \mathrm{M}$ ) was found (data not shown).
To test the involvement of ghrelin in the regulation of osteoclastogenesis, due to its stimulatory action on OPG expression, we examined the effects of conditioned media from rat osteoblasts treated with ghrelin, on osteoclast precursors. Osteoclast precursors cells were obtained by bone marrow of long bones and cultured for seven days in conditioned media obtained from $\mathrm{rOB}$ treated with or without Ghrelin $10^{-10} \mathrm{M}$ for 24 and $48 \mathrm{~h}$, in the presence of M-CSF $(25 \mathrm{ng} / \mathrm{mL})$ and of a subeffective dose of RANKL $(50 \mathrm{ng} / \mathrm{mL})$. The presence of osteoclast-like cells was evaluated by counting the number of multinucleated TRAcP positive cells per well. The number of osteoclasts was significantly reduced as compared with that detected incubating osteoclast precursors 


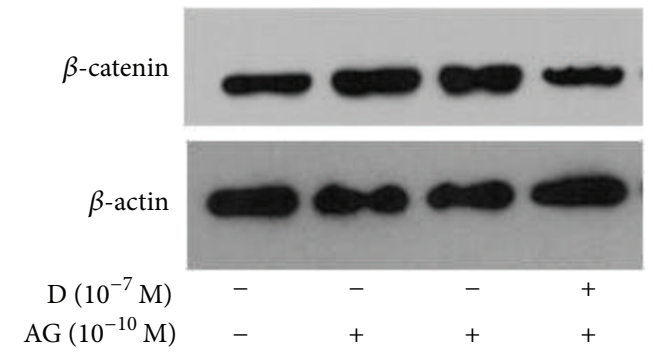

(a)

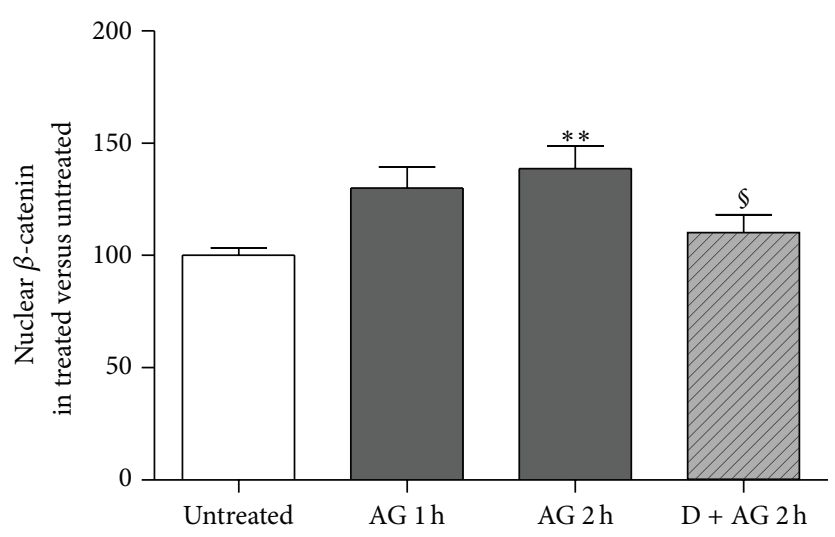

(b)

Figure 3: Representative Western blot (a) and quantification (b) of $\beta$-catenin levels in the enriched nuclear fraction of rat osteoblast-like cells exposed to ghrelin (AG, $10^{-10} \mathrm{M}$ for 1 and $2 \mathrm{~h}$ ) alone or together with D-Lys ${ }^{3}$-GHRP-6 (D, $10^{-7} \mathrm{M} 30$ min before AG), a GHSR-la receptor antagonist. $\beta$-catenin levels are normalized on $\beta$-actin protein levels and results are expressed as the ratio of $\beta$-catenin amount measured in treated cells to the amount obtained in untreated cells. Data are the mean \pm SEM of five experiments ${ }^{* *} P<0.01$ versus untreated; ${ }^{\circledR} P<0.05$ versus $2 \mathrm{~h}$ AG treated cells.

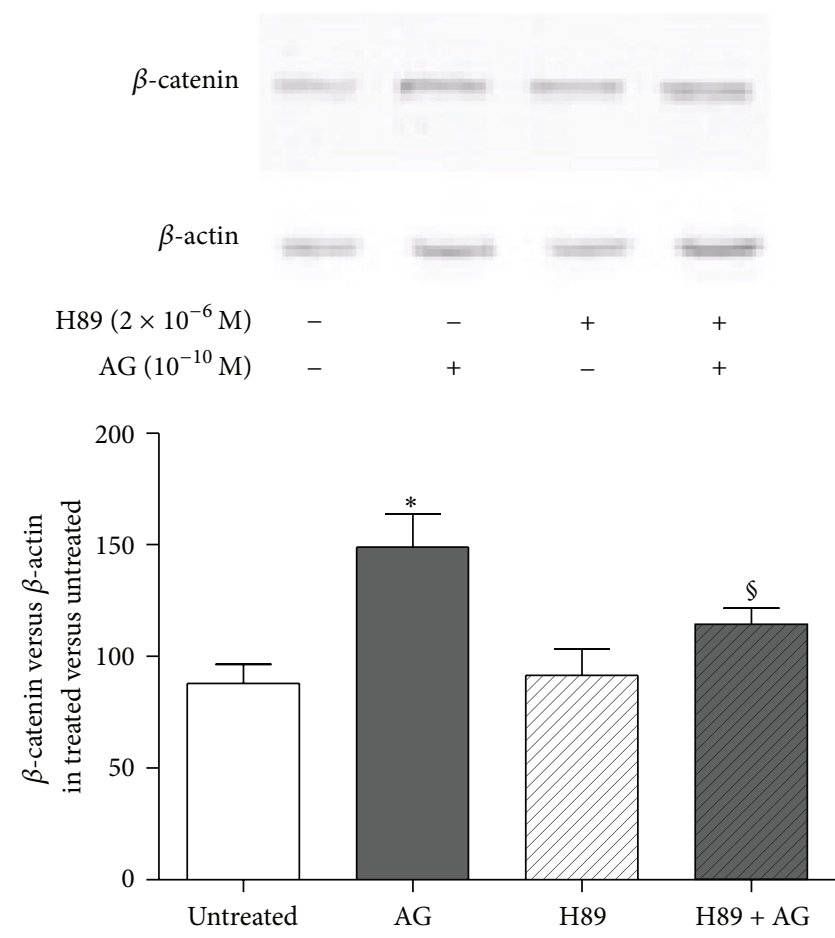

(a)

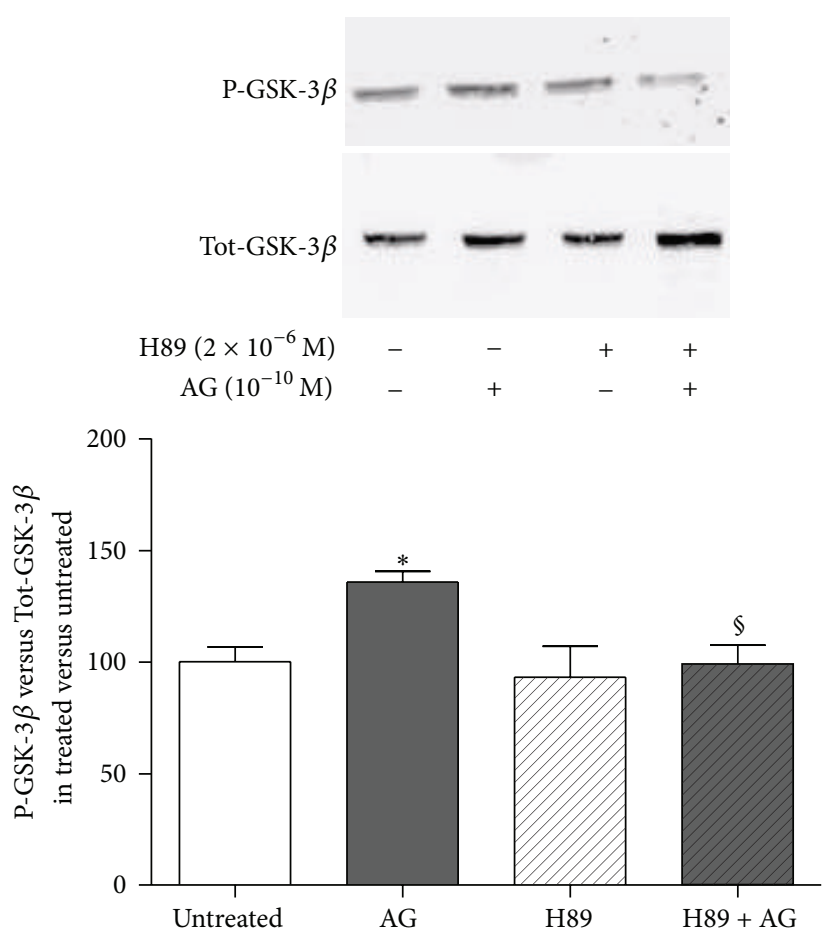

(b)

Figure 4: Effect of the pretreatment with the PKA inhibitor H89 $\left(2 \times 10^{-6} \mathrm{M}, 30\right.$ min before) on (a) $\beta$-catenin and (b) phosphorylated-GSK3 $\beta$ $(\mathrm{P}-\mathrm{GSK} 3 \beta)$ levels measured in whole cell lysates by Western blot on rat osteoblast-like cells (rOB) treated with ghrelin $\left(\mathrm{AG}, 10^{-10} \mathrm{M}\right.$ for $\left.1 \mathrm{~h}\right)$. $\beta$-catenin levels were normalized to $\beta$-actin levels; P-GSK3 $\beta$ was normalized to total GSK3 $\beta$ levels (Tot-GSK3 $\beta$ ). Results are expressed as ratio of $\beta$-catenin or P-GSK3 $\beta$ measured in treated cells versus untreated cells. Insets: typical gels obtained from rOB cell lysates after treatment with ghrelin alone or together with H89. Data are the mean \pm SEM of 5 experiments ${ }^{*} P<0.05$ versus untreated cells; ${ }^{\circledR} P<0.05$ versus AG treated cells. 


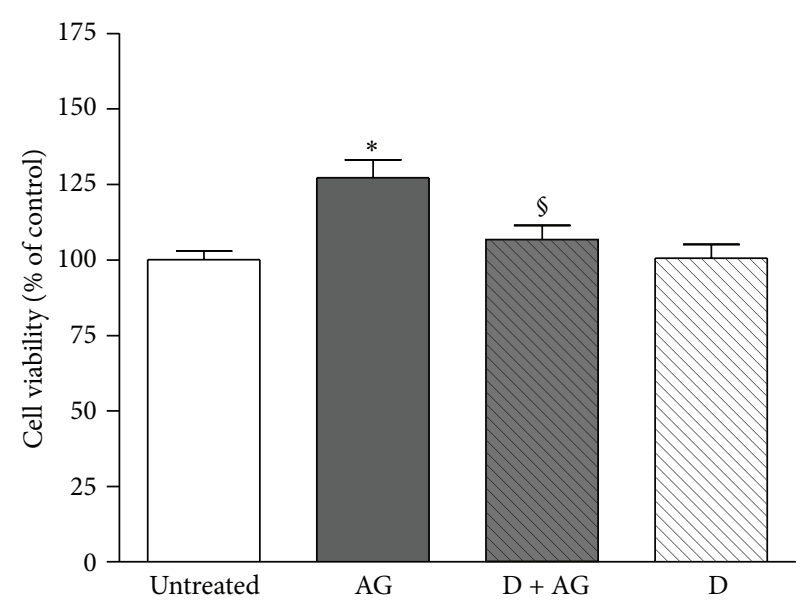

(a)

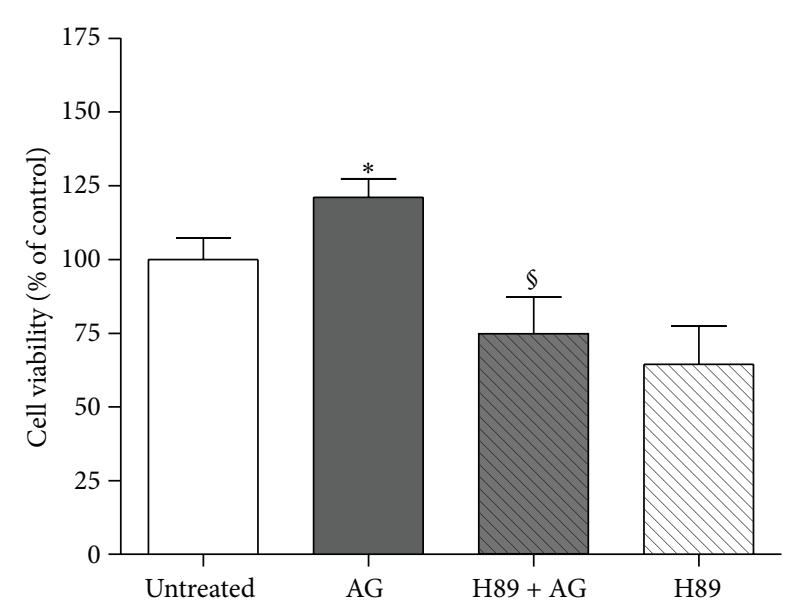

(b)

Figure 5: Effect of pretreatment with (a) D-Lys ${ }^{3}$-GHRP-6 (D, $10^{-7} \mathrm{M}, 30 \mathrm{~min}$ before AG) or (b) the PKA inhibitor H89 ( $2 \times 10^{-6} \mathrm{M}, 30 \mathrm{~min}$ before AG) on the stimulatory action of ghrelin $\left(\mathrm{AG}, 10^{-10} \mathrm{M}\right)$ on rat osteoblast-like cells (rOB) viability. Cell viability was measured by MTT assay. Data are expressed as the percentage relative to control and are the means \pm SEM of four replicates within a single experiment that was repeated at least three times. ${ }^{*} P<0.05$ versus untreated cells; ${ }^{\circ} P<0.05$ versus AG.

with medium from untreated-control osteoblasts, when bone marrow precursors were exposed to conditioned media from $48 \mathrm{~h}$ ghrelin- $\left(10^{-10} \mathrm{M}\right)$ treated $\mathrm{rOB}$, (Figure 7$)$.

\section{Discussion}

In the present study we have shown that the anabolic action of ghrelin involves an increase in the $\beta$-catenin levels in primary rat osteoblastic cells. This effect is mediated by GHS-Rla as its specific antagonist, D-Lys ${ }^{3}$-GHRP-6, blocks it. Our findings indicate that the effect of ghrelin on $\beta$-catenin accumulation is due to inhibition of GSK-3 $\beta$ activation via cAMP/PKA pathway since the inhibition of the enzyme activity by $\mathrm{H} 89$ reduces ghrelin activity. Consistently with the activation of Wnt signaling, ghrelin also increases the expression of OPG and decreases RANKL/OPG ratio leading to reduced osteoblast-related osteoclast formation.

Several studies have shown anabolic action of ghrelin on bone [5-7]; however the mechanisms for this effect remain to be fully elucidated. One possible mechanism includes the secretagogue action of ghrelin on growth hormone [22]. However, it is unlikely that the effects of ghrelin on bone are exclusively mediated through a GH/IGF-1 axis since ghrelin administration increases bone mass in genetically GH-deficient rats [5].

Conversely, our study was based on the hypothesis that ghrelin, acting on osteoblasts, could exert a direct anabolic action through an autocrine/paracrine way that involves Wnt/ $\beta$-catenin canonical pathway: a critical signaling controlling osteoblasts at different levels, that is, commitment, proliferation, apoptosis and function [23]. In the absence of active Wnt ligands, $\beta$-catenin is bound to the scaffold proteins Axin and adenomatous polyposis coli (APC) and constitutively phosphorylated via interaction with casein kinase I and GSK3- $\beta$. The presence of Wnt ligands inhibits the kinase activity of GSK-3 $\beta$ leading to $\beta$-catenin accumulation in the cytoplasm followed by its translocation into the nucleus where it interacts with $\mathrm{T}$ cell factor/lymphoid enhancer family members to induce the transcription of key osteoblastic genes [24]. Canonical Wnt signaling is crucial for osteoblastogenesis and bone formation since loss or gain of function of $\beta$-catenin is associated with a decrease or an increase of bone mass, respectively [25]. Here we showed that ghrelin increased $\beta$-catenin cytoplasmic levels leading to the nuclear translocation of the protein. The effect was obtained under physiological dosages of ghrelin to show its fine regulation of bone cells; its magnitude was in agreement with data recently observed in other systems [26]; it was dose and time dependent and it was consistent with the inhibition of GSK-3 $\beta$ : a critical element of $\beta$-catenin activation.

The observation that ghrelin increases GSK- $3 \beta$ phosphorylation (Figure 2(a)) suggests that ghrelin promotes $\beta$ catenin stabilization by downregulating its inhibitory pathway. Our data are in agreement with previous studies showing that the activation of phosphorylated GSK- $3 \beta / \beta$-catenin activity is involved in the beneficial effects of ghrelin against hypoxia-induced pulmonary hypertension in the rat [27] and ischemic neural injury $[20,28]$. In our study, the direct effect of PKA on GSK-3 $\beta$ was documented since H89 nullified ghrelin effect on GSK-3 $\beta$ activity. The direct effect of PKA on $\beta$-catenin phosphorylation and degradation seems to be ruled out on the basis of the present results showing that pretreatment with H89 increased $\beta$-catenin level instead of reducing it.

Moreover, our results sustain the emerging view that several classes of hormones and peptides activate $\beta$-catenin signaling through PKA dependent inhibition of GSK-3 $\beta$ as was demonstrated for PTH [29] and calcitonin gene related peptide [30]. The activation of Wnt signaling through GSK$3 \beta$ inhibition and vice versa is in fact becoming a critical 


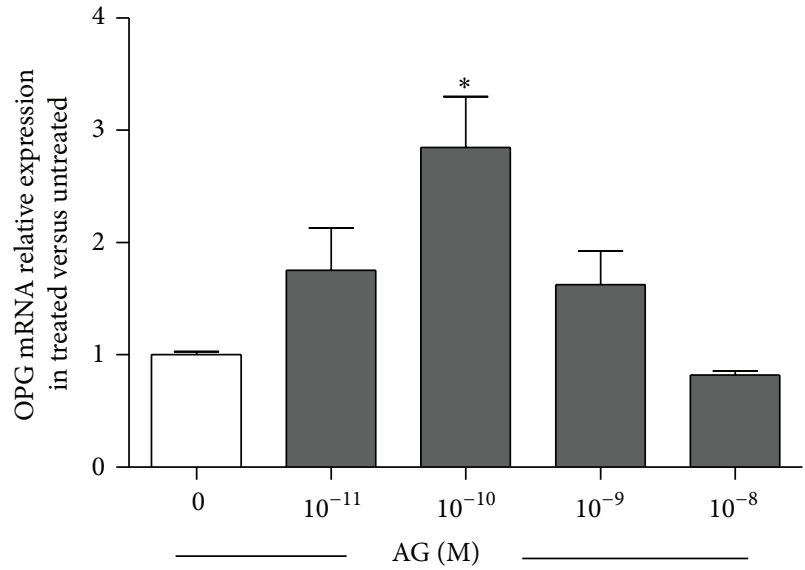

(a)

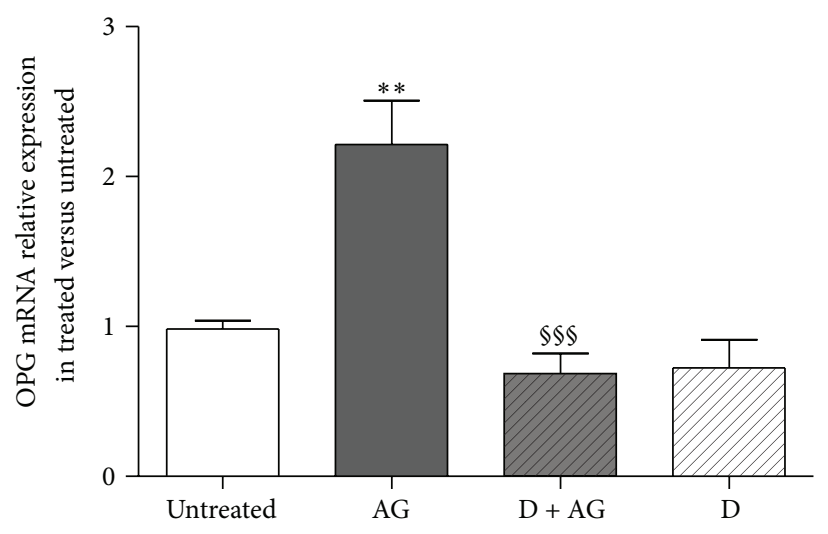

(b)

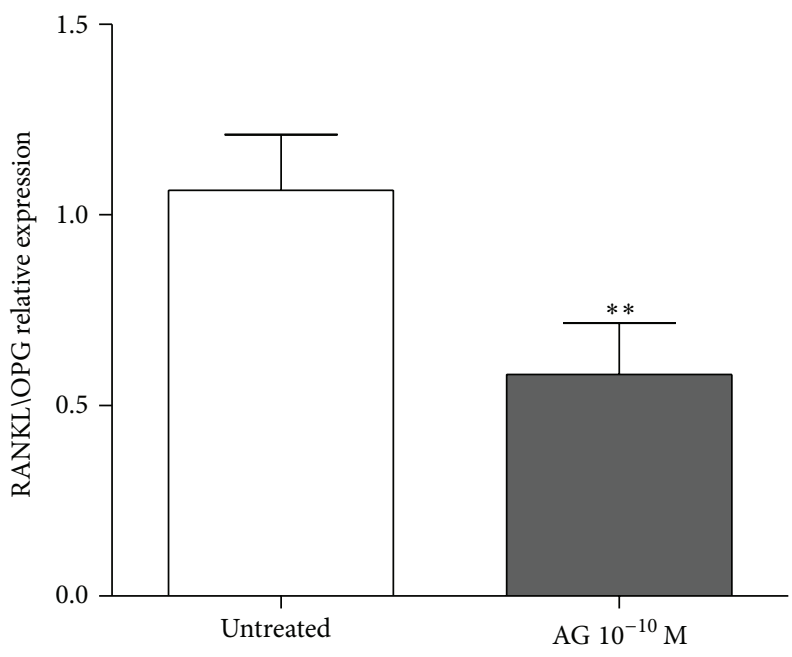

(c)

FIGURE 6: Effect of increasing concentrations of ghrelin (AG, $10^{-11} \mathrm{M}-10^{-7} \mathrm{M}$ ) on osteoprotegerin (OPG) expression measured by real-time PCR at $24 \mathrm{~h}$ after AG treatment in primary cultures of rat osteoblast-like cells (a). Effect of pretreatment (30 min before) with the GHSR-1a antagonist D-Lys ${ }^{3}$-GHRP-6 (D, $\left.10^{-7} \mathrm{M}\right)$ on the stimulatory action of AG $\left(10^{-10} \mathrm{M}\right.$ for $24 \mathrm{~h}$ ) on OPG expression (b). Ratio of RANKL/OPG relative expression measured in untreated and $A G 10^{-10} \mathrm{M}$ treated rat osteoblasts after $24 \mathrm{~h}$ (c). OPG and RANKL expression were normalized to that of GAPDH and expressed as $2^{-\Delta \Delta \mathrm{Ct}}$. Three replicates were performed for each experimental point and experiments were repeated three times. ${ }^{*} P<0.05 ;{ }^{* *} P<0.01$ versus untreated cells. ${ }^{\S \S} P<0.001$ versus AG treated cells.

element for the full understanding of the anabolic role of Wnt [31]. Besides the possible involvement of a receptor other than GHS-R1a in ghrelin dependent bone metabolism regulation [19], our study has demonstrated the importance of GHS-R1a in the activation of the Wnt signaling in osteoblast.

Considering that GHS-Rla has been identified in osteoblasts $[1,7]$ and that at the moment the only acknowledged ghrelin receptor is GHS-Rla, we examined the involvement of this receptor in the stimulatory action of ghrelin on $\beta$-catenin levels. GHS-Rla involvement was proven by the fact that the specific GHS-Rla antagonist, D-Lys ${ }^{3}$-GHRP-6, abolished the stimulatory action of ghrelin on $\beta$-catenin, indicating that this ghrelin effect is GHS-Rla- mediated. These results fit also well with the report that GHS-Rla is involved in the stimulatory action of ghrelin on osteoblast proliferation [5] and with the present results showing that D-Lys ${ }^{3}$-GHRP-6 reduced the stimulatory action of ghrelin on osteoblast viability. Furthermore, upregulation of phosphorylation of GSK$\beta / \beta$-catenin signaling in the presence of GHS-Rla protected neonatal rats from hypoxia-induced pulmonary hypertension [27].

Stimulation of ghrelin receptor leads to activation of multiple downstream signaling.

Kim and colleagues [6] have shown that ghrelin promotes osteoblast proliferation and differentiation through MAPK/ ERK and PI3K/AKT signaling pathways, but cAMP-mediated PKA pathway was not examined. It is likely that the effects of ghrelin on $\beta$-catenin accumulation involve PKA activation since inhibition of the enzyme activity by H89 abrogated the stimulatory action of ghrelin on $\beta$-catenin levels. Any potential bias due to the effect of H89 on cell differentiation was controlled by the short term (1 hour) exposure of 


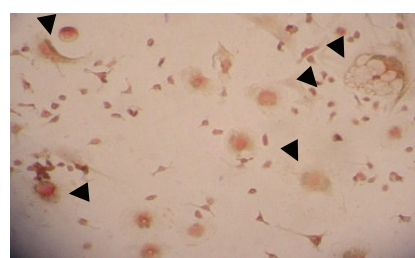

CM untreated

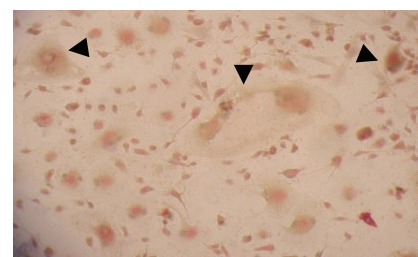

CM 24 h AG

RANKL + M-CSF

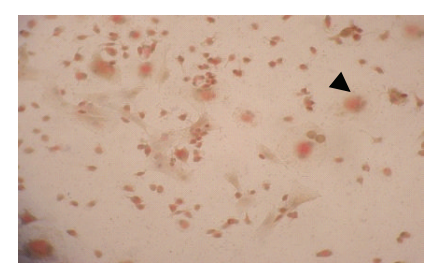

CM 48 h AG

(a)

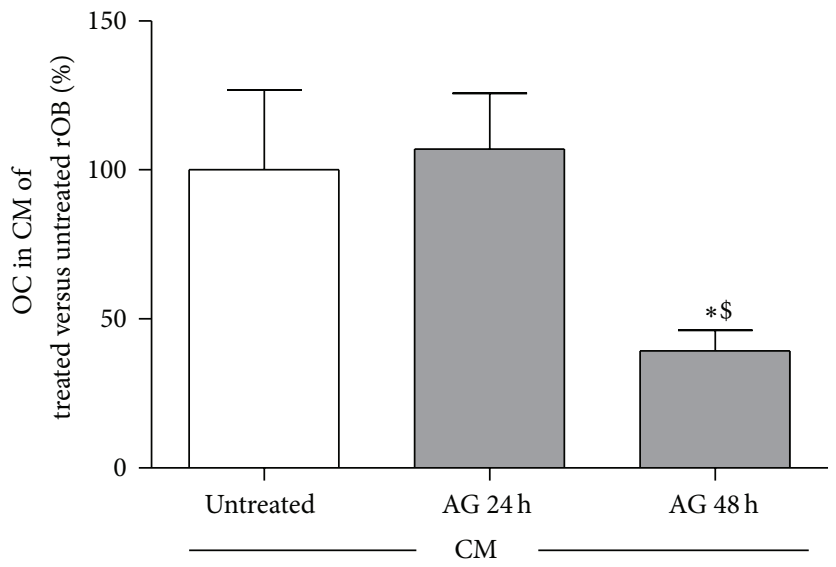

(b)

Figure 7: Effect of conditioned media (CM) obtained from rat osteoblast-like cells (rOB) treated without or with ghrelin (AG, $10^{-10} \mathrm{M}$ for 24 or $48 \mathrm{~h}$ ) on osteoclast formation, in presence of $50 \mathrm{ng} / \mathrm{mL}$ RANKL and $25 \mathrm{ng} / \mathrm{mL}$ M-CSF. Black arrows: multinucleated tartrate-resistant acid phosphatase positive (TRAP+) cells (a). The percentage of TRAP+ multinucleated cells ( $\geq 3$ nuclei) formed after 7 days culture with conditioned media obtained from untreated and treated (AG, $10^{-10} \mathrm{M}$ for 24 or 48 ) rOB (b). ${ }^{*} \mathrm{P}<0.05$ versus $\mathrm{CM}$ of untreated cells; ${ }^{\$} \mathrm{P}<0.05$ versus $\mathrm{CM}$ of $\mathrm{rOB}$ treated for $24 \mathrm{~h}$ with $\mathrm{AG}$.

the cultures. It remains to be clarified whether ghrelininduced $\beta$-catenin stabilization via cAMP-dependent protein kinase activation involves only the inhibition of GSK-3 $\beta$.

A number of recent reports showed that the phosphorylation of $\beta$-catenin on ser552 by PKA enhances the transcriptional ability of $\beta$-catenin independent of the phosphorylation of $\beta$-catenin in the $\mathrm{N}$-terminal domain at canonical sites regulated by Wnt pathway $[32,33]$. This molecular mechanism of PKA-dependent $\beta$-catenin stabilization could be involved in ghrelin-induced $\beta$-catenin cytoplasmatic accumulation. Our data show that ghrelin enhances rOB viability through GHSRla and PKA activation and, by acting on the same pathways, promotes stabilization of intracellular $\beta$ catenin levels. Therefore, we can speculate that the anabolic action of ghrelin in $\mathrm{rOB}$ is exerted through $\beta$-catenin stabilization. Further studies will be required to examine the direct involvement of $\beta$-catenin stabilization in ghrelin enhancement of $\mathrm{rOB}$ viability.

Loss- and gain-of-function mutations of $\beta$-catenin in osteoblasts affect not only bone formation but also bone resorption and osteoclast differentiation due to deregulation of the OPG gene. Activation of the Wnt/ $\beta$-catenin pathway in osteoblasts suppresses bone resorption through upregulation of OPG expression and downregulation of RANKL expression $[34,35]$.
Our results show that ghrelin stimulates OPG expression and that pretreatment with the GHS-Rla antagonist, D-Lys ${ }^{3}$ GHRP-6, abolished the stimulatory action of ghrelin on OPG, thus indicating that ghrelin effects on OPG are specific and receptor mediated. The evidence that ghrelin induces OPG gene expression and reduces RANKL/OPG ratio suggests for the peptide an inhibitory role on osteoclastogenesis. This assumption is in line with the results obtained by exposing bone marrow precursor cells to the conditioned medium after $24 \mathrm{hr}$ and $48 \mathrm{hr}$ treatment with ghrelin. As expected, from the understanding of the OPG/RANK/RANKL system [36], we found that conditioned media from rOB treated with ghrelin inhibited, indeed, the development of TRAcP+ cells from bone marrow precursors. In Figure 7, panel A, typical multinucleated osteoclasts are outlined in the three experimental conditions and quantified in panel B.

It remains to be clarified whether ghrelin could have a direct action on osteoclastogenesis since the peptide is present in conditioned medium (CM) from rOB. This hypothesis is unlikely because CM from $24 \mathrm{~h}$ treated cells had no effect on multinucleated TRAcP positive cell formation. Consistent with this view is the here observed presence of the effect at 48 hours (Figure 7 ) that follows the earlier reduction of RANKL/OPG ratio at $24 \mathrm{~h}$ (Figure 6(c)), and the absence of a stimulatory effect by ghrelin on osteoclast differentiation observed by others in mouse bone marrow cultures [8]. 
Our data show a stimulatory action of ghrelin on OPG expression and consequently an inhibition of osteoblast mediated osteoclastogenesis and corroborate the results of Delhanty and colleagues [37] that demonstrated that osteoclastogenesis was faster in bone marrow cultures from ghrelin receptor deficient and ghrelin deficient mice and that ghrelin induced OPG expression in mouse osteoblastic cultures. Since D-Lys ${ }^{3}$-GHRP-6 abolished ghrelin effect on OPG expression in $\mathrm{rOB}$, we can speculate that ghrelin affects indirectly osteoclastogenesis by binding GHS-Rla in primary rat osteoblasts. Our findings are in line with previous in vivo studies with hexarelin, a synthetic GH secretagogue that recognizes GHS-Rla. It has been reported, in fact, that long-term hexarelin administration inhibits bone resorption induced by gonadectomy in the rat [14]. Contrasting results have been reported on the effects of ghrelin on osteoclast activity. Costa and colleagues [8] have shown that ghrelin at a concentration of $10^{-9} \mathrm{M}$ increased the bone resorption activity of mature rat osteoclasts but did not modify osteoclast differentiation in mouse bone marrow cultures. However, the conditioned medium used in our experimental condition mimics the inhibitory effect of OPG addition in the osteoclastogenesis assay applied by Costa et al. [8]. More recently, van der Velde and colleagues [11] reported that ghrelin has a direct negative effect and indirect age-dependent positive action on osteoclastogenesis via a systemic pathway that is controlled by leptin. The importance of ghrelin in contrasting the "ageing" effect could be confirmed by our very preliminary data indicating that ghrelin $\left(10^{-8} \mathrm{M}\right)$ induces a global hypermethylation of primary rat osteoblasts DNA (data not shown). This effect might counteract the typical global hypomethylation of DNA present in postmenopausal women with osteoporosis [38].

More research on this complex but fascinating area of gerontology and future in vitro and in vivo studies will be required to clarify the role of ghrelin in the regulation of bone turnover and to suggest the potential utility of GHS-R1aagonists to stimulate bone formation and to inhibit osteoclastogenesis, thus improving bone structure in conditions such as osteoporosis.

\section{Conflict of Interests}

The authors declare that there is no conflict of interests that could be perceived as prejudicing the impartiality of the research reported.

\section{Acknowledgment}

This work was supported by funds from FIRST 2009 to Valeria Sibilia.

\section{References}

[1] D. Cocchi, G. Maccarinelli, V. Sibilia et al., "GH-releasing peptides and bone," Journal of Endocrinological Investigation, vol. 28 , no. 8 , supplement, pp. 11-14, 2005.
[2] M. van der Velde, P. Delhanty, B. van der Eerden, A. J. van der Lely, and J. van Leeuwen, "Ghrelin and Bone," Vitamins and Hormones, vol. 77, pp. 239-258, 2007.

[3] D. Nikolopoulos, S. Theocharis, and G. Kouraklis, "Ghrelin, another factor affecting bone metabolism," Medical Science Monitor, vol. 16, no. 7, pp. R147-R162, 2010.

[4] P. J. D. Delhanty, B. C. J. van der Eerden, and J. P. T. M. van Leeuwen, "Ghrelin and bone," BioFactors, vol. 40, no. 1, pp. 4148, 2014.

[5] N. Fukushima, R. Hanada, H. Teranishi et al., "Ghrelin directly regulates bone formation," Journal of Bone and Mineral Research, vol. 20, no. 5, pp. 790-798, 2005.

[6] S. W. Kim, S. J. Her, S. J. Park et al., "Ghrelin stimulates proliferation and differentiation and inhibits apoptosis in osteoblastic MC3T3-E1 cells," Bone, vol. 37, no. 3, pp. 359-369, 2005.

[7] G. Maccarinelli, V. Sibilia, A. Torsello et al., "Ghrelin regulates proliferation and differentiation of osteoblastic cells," Journal of Endocrinology, vol. 184, no. 1, pp. 249-256, 2005.

[8] J. L. Costa, D. Naot, J.-M. Lin et al., "Ghrelin is an osteoblast mitogen and increases osteoclastic bone resorption in vitro," International Journal of Peptides, vol. 2011, Article ID 605193, 7 pages, 2011.

[9] Q.-H. Liang, Y. Liu, S.-S. Wu, R.-R. Cui, L.-Q. Yuan, and E.-Y. Liao, "Ghrelin inhibits the apoptosis of MC3T3-E1 cells through ERK and AKT signaling pathway," Toxicology and Applied Pharmacology, vol. 272, no. 3, pp. 591-597, 2013.

[10] H. Inoue, Y. Sakamoto, N. Kangawa et al., "Analysis of expression and structure of the rat GH-secretagogue/ghrelin receptor (Ghsr) gene: roles of epigenetic modifications in transcriptional regulation," Molecular and Cellular Endocrinology, vol. 345, no. 1-2, pp. 1-15, 2011.

[11] M. van der Velde, B. C. van der Eerden, Y. Sun et al., "An age-dependent interaction with leptin unmasks ghrelin's boneprotective effects," Endocrinology, vol. 153, no. 8, pp. 3593-3602, 2012.

[12] H. J. Choi, K. H. Ki, J.-Y. Yang et al., "Chronic central administration of Ghrelin increases bone mass through a mechanism independent of appetite regulation," PLoS ONE, vol. 8, no. 7, Article ID e65505, 2013.

[13] J. Svensson, S. Lall, S. L. Dickson et al., “The GH secretagogues ipamorelin and GH-releasing peptide- 6 increase bone mineral content in adult female rats," The Journal of Endocrinology, vol. 165, no. 3, pp. 569-577, 2000.

[14] V. Sibilia, D. Cocchi, F. Pagani et al., "Hexarelin, a growth hormone-releasing peptide, counteracts bone loss in gonadectomized male rats," Growth Hormone \& IGF Research, vol. 9, no. 4, pp. 219-227, 1999.

[15] V. Sibilia, D. Cocchi, I. Villa et al., "Bone effects of hexarelin, a GH-releasing peptide, in female rats: influence of estrogen milieu," European Journal of Endocrinology, vol. 146, no. 6, pp. 855-862, 2002.

[16] N. Napoli, C. Pedone, P. Pozzilli et al., "Effect of ghrelin on bone mass density: the InChianti study," Bone, vol. 49, no. 2, pp. 257263, 2011.

[17] P. Amini, F. Cahill, D. Wadden et al., "Beneficial association of serum ghrelin and peptide YY with bone mineral density in the Newfoundland population," BMC Endocrine Disorders, vol. 13, article 35, 2013.

[18] S. Gonnelli, C. Caffarelli, K. del Santo et al., "The relationship of ghrelin and adiponectin with bone mineral density and bone turnover markers in elderly men," Calcified Tissue International, vol. 83, no. 1, pp. 55-60, 2008. 
[19] P. J. Delhanty, B. C. van der Eerden, M. van der Velde et al., "Ghrelin and unacylated ghrelin stimulate human osteoblast growth via mitogen-activated protein kinase (MAPK)/phosphoinositide 3-kinase (PI3K) pathways in the absence of GHSRla," Journal of Endocrinology, vol. 188, no. 1, pp. 37-47, 2006.

[20] H. Chung, E. Kim, D. H. Lee et al., "Ghrelin inhibits apoptosis in hypothalamic neuronal cells during oxygen-glucose deprivation," Endocrinology, vol. 148, no. 1, pp. 148-159, 2007.

[21] A. Novak and S. Dedhar, "Signaling through $\beta$-catenin and Lef/Tcf," Cellular and Molecular Life Sciences, vol. 56, no. 5-6, pp. 523-537, 1999.

[22] M. Kojima, H. Hosoda, Y. Date, M. Nakazato, H. Matsuo, and $\mathrm{K}$. Kangawa, "Ghrelin is a growth-hormone-releasing acylated peptide from stomach," Nature, vol. 402, no. 6762, pp. 656-660, 1999.

[23] R. Baron and M. Kneissel, "WNT signaling in bone homeostasis and disease: from human mutations to treatments," Nature Medicine, vol. 19, no. 2, pp. 179-192, 2013.

[24] K. Maeda, N. Takahashi, and Y. Kobayashi, "Roles of Wnt signals in bone resorption during physiological and pathological states," Journal of Molecular Medicine, vol. 91, no. 1, pp. 15-23, 2013.

[25] D. G. Monroe, M. E. McGee-Lawrence, M. J. Oursler, and J. J. Westendorf, "Update on Wnt signaling in bone cell biology and bone disease," Gene, vol. 492, no. 1, pp. 1-18, 2012.

[26] B. Li, M. Zeng, W. He et al., " Grelin protects alveolar macrophages against lipopolysaccharide-induced apoptosis through dependent c-Jun N-terminal kinase and Wnt/ $\beta$-catenin signaling and suppresses lung inflammation," Endocrinology, vol. 156, no. 1, pp. 203-217, 2015.

[27] Y.-P. Xu, J.-J. Zhu, F. Cheng et al., "Ghrelin ameliorates hypoxiainduced pulmonary hypertension via phospho-GSK3 $\beta / \beta$-catenin signaling in neonatal rats," Journal of Molecular Endocrinology, vol. 47, no. 1, pp. 33-43, 2011.

[28] H. Chung, E. Li, Y. Kim, S. Kim, and S. Park, "Multiple signaling pathways mediate ghrelin-induced proliferation of hippocampal neural stem cells," Journal of Endocrinology, vol. 218, no. 1, pp. 49-59, 2013.

[29] A. Suzuki, K. Ozono, T. Kubota, H. Kondou, K. Tachikawa, and T. Michigami, "PTH/cAMP/PKA signaling facilitates canonical Wnt signaling via inactivation of glycogen synthase kinase- $3 \beta$ in osteoblastic Saos-2 cells," Journal of Cellular Biochemistry, vol. 104, no. 1, pp. 304-317, 2008.

[30] E. Mrak, F. Guidobono, G. Moro, G. Fraschini, A. Rubinacci, and I. Villa, "Calcitonin gene-related peptide (CGRP) inhibits apoptosis in human osteoblasts by $\beta$-catenin stabilization," Journal of Cellular Physiology, vol. 225, no. 3, pp. 701-708, 2010.

[31] C. Metcalfe and M. Bienz, "Inhibition of GSK3 by Wnt signalling-two contrasting models," Journal of Cell Science, vol. 124, no. 21, pp. 3537-3544, 2011.

[32] S. Taurin, N. Sandbo, Y. Qin, D. Browning, and N. O. Dulin, "Phosphorylation of $\beta$-catenin by cyclic AMP-dependent protein kinase," The Journal of Biological Chemistry, vol. 281, no. 15, pp. 9971-9976, 2006.

[33] D. Fang, D. Hawke, Y. Zheng et al., "Phosphorylation of betacatenin by AKT promotes beta-catenin transcriptional activity," The Journal of Biological Chemistry, vol. 282, no. 15, pp. 1122111229, 2007.

[34] D. A. Glass II, P. Bialek, J. D. Ahn et al., "Canonical Wnt signaling in differentiated osteoblasts controls osteoclast differentiation," Developmental Cell, vol. 8, no. 5, pp. 751-764, 2005.
[35] G. J. Spencer, J. C. Utting, S. L. Etheridge, T. R. Arnett, and P. G. Genever, "Wnt signalling in osteoblasts regulates expression of the receptor activator of $\mathrm{NF} \kappa \mathrm{B}$ ligand and inhibits osteoclastogenesis in vitro," Journal of Cell Science, vol. 119, no. 7, pp. 1283-1296, 2006.

[36] S. Theoleyre, Y. Wittrant, S. K. Tat, Y. Fortun, F. Redini, and D. Heymann, "The molecular triad OPG/RANK/RANKL: involvement in the orchestration of pathophysiological bone remodeling," Cytokine \& Growth Factor Reviews, vol. 15, no. 6, pp. 457-475, 2004.

[37] P. J. D. Delhanty, M. van der Velde, B. C. J. van der Eerden et al., "Genetic manipulation of the ghrelin signalling system in male mice reveals bone compartment specificity of acylated and unacylated ghrelin in the regulation of bone remodelling," Endocrinology, vol. 155, no. 11, pp. 4287-4295, 2014.

[38] P. Jintaridth, R. Tungtrongchitr, S. Preutthipan, and A. Mutirangura, "Hypomethylation of Alu elements in post-menopausal women with osteoporosis," PLoS ONE, vol. 8, no. 8, Article ID e70386, 2013. 


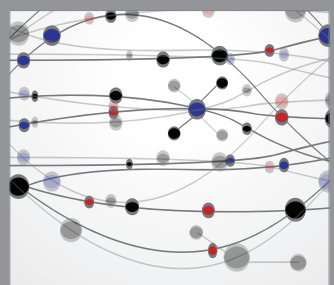

The Scientific World Journal
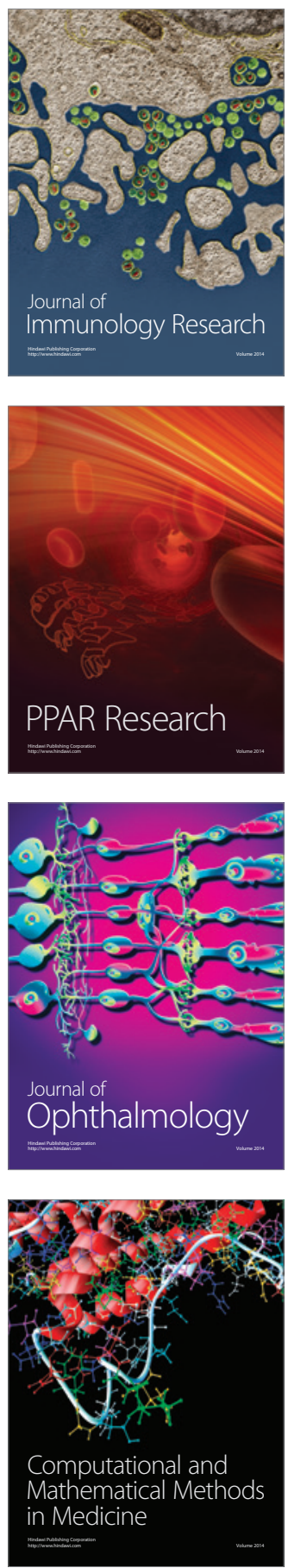

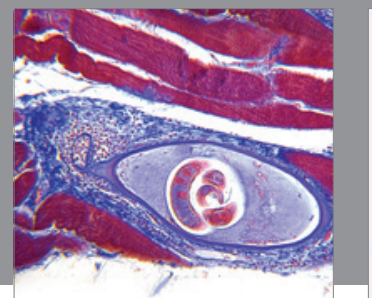

Gastroenterology

Research and Practice
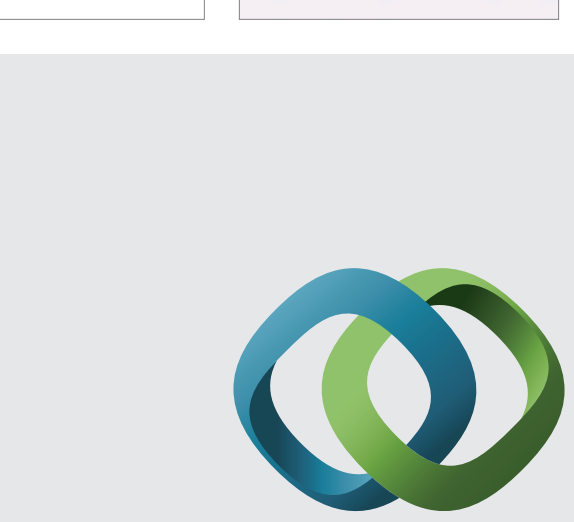

\section{Hindawi}

Submit your manuscripts at

http://www.hindawi.com
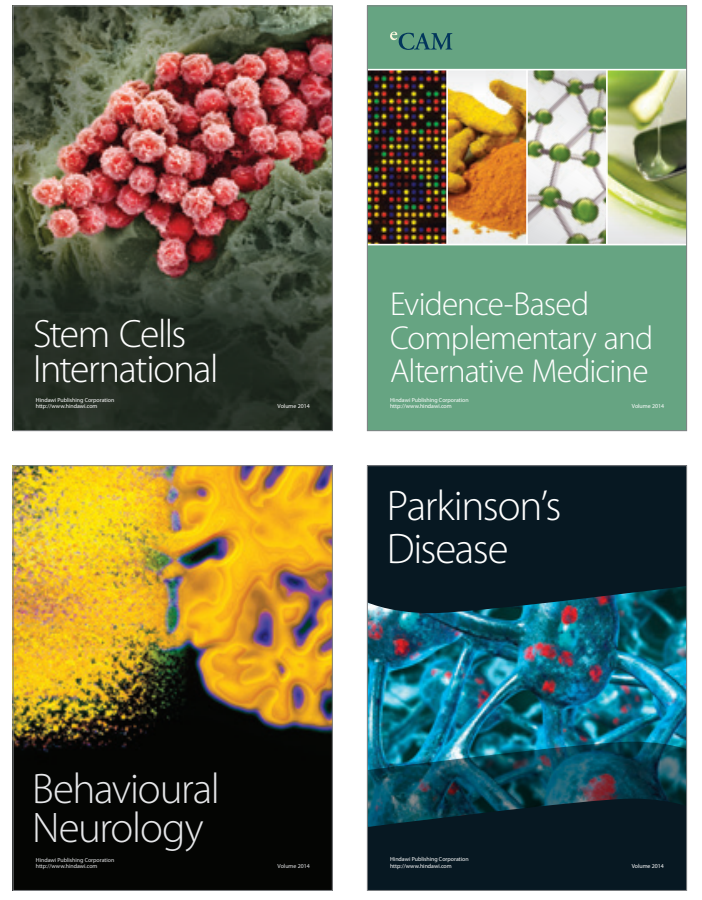
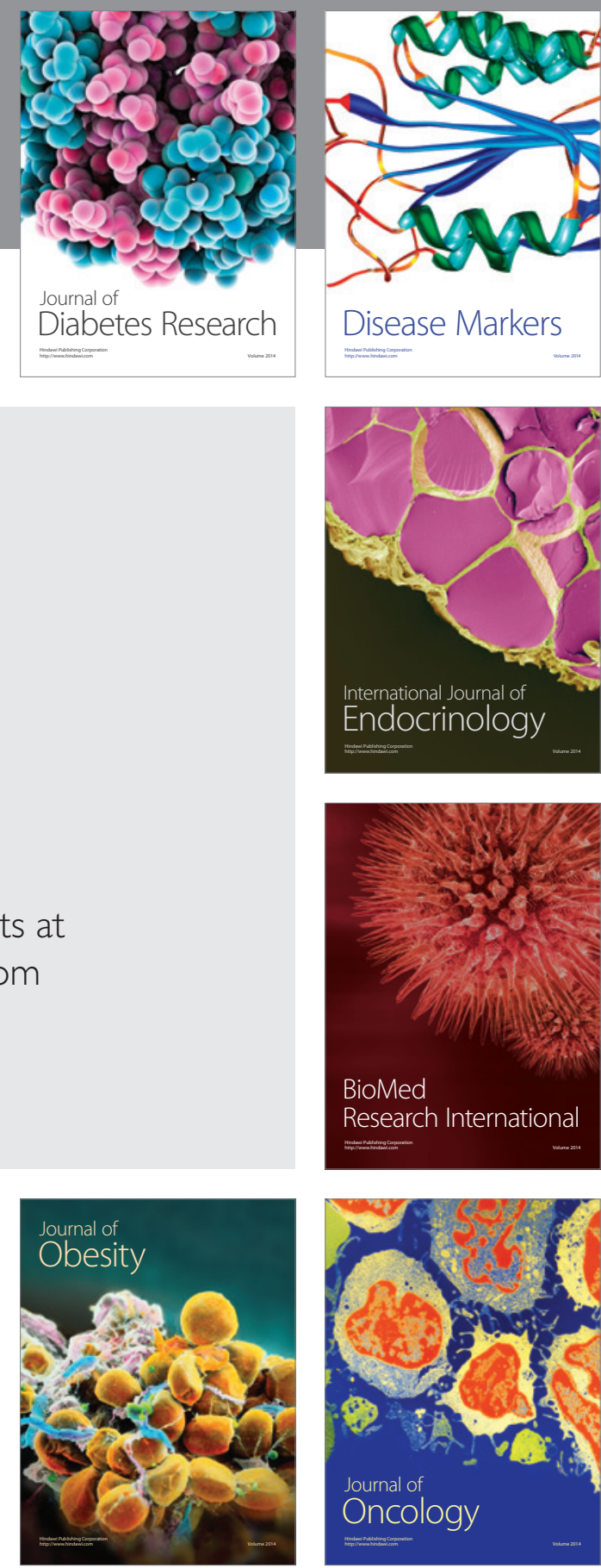

Disease Markers
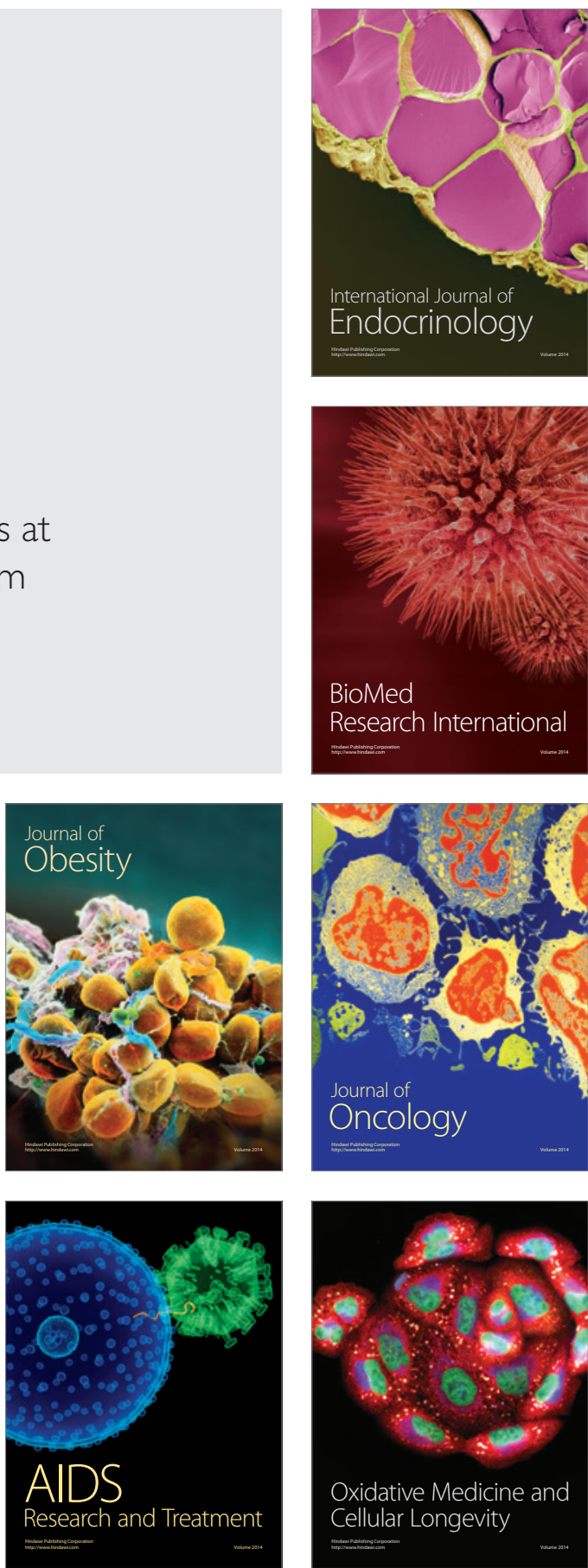